\title{
Environmental Diagnosis of Risk Areas Related to Gas Stations
}

\author{
Luiz Eduardo Moschini*, José Eduardo dos Santos and José Salatiel Rodrigues Pires \\ PPG-ERN/UFSCar; Via Washington Luiz, Km 235; C. P. 676; 13565-905; São Carlos - SP - Brasil
}

\begin{abstract}
Studies were carried out on the localization and mapping of gas stations in the urban area of São Carlos city, for an environmental diagnosis related to soil, surface water and underground water contamination resulting from likely leaking in fuel underground storage tanks. Considering that a provision of legal restriction makes it possible that most of public areas are not located in gas station areas of potential risk, these information are useful for the development of programs designed to reduce risks to public safety and health and of the soil, surface water and underground water contamination.
\end{abstract}

Key-words: Gas station; undergrounded storage tank; high risk area

\section{INTRODUCTION}

One of the major contamination sources of the soil, air, underground and surface water has been related to liquid fuel tank leakings, processed chemical products, toxic chemical products and diluted rejects. As of 1985, fuel underground storage tanks became a priority in the United States, leading to the regulation, by the Environmental Protection Agency (EPA) of prevention, detection and fixing of leaking in the tanks, as well as to the creation of a specific agency (Office of Underground Storage Tanks) to supervise these aspects (EPA, 1984; 1985a;b).

Fuel underground storage tanks in the United States amount to approximately three million units, and according to conservative estimates, some $10 \%$ of them can be leaking (Canter et al., 1988). Sealing tests in fuel underground storage tanks of São Paulo city show that approximately $80 \%$ of them have some type of leaking in the suction line or in the storage tank itself (Oliveira,
1992). The most common causes for leaking are related to structural deficiencies, mainly a result of inappropriate installation of fuel storage tanks and corrosion of their internal and/or external lining (Pearson and Oudjik, 1993). In Brazil, corrosion is considered the main cause of leaking, since most of fuel storage tanks do not have a protective external lining and have been in use for more than 20 years (Oliveira, 1992).

Most of the fuel underground storage tanks store petroleum or its by-products represented by aliphatic or aromatic hydrocarbons. Gasoline, for example, is composed of more than 70 hydrocarbons, including aliphatic hydrocarbons, such as pentane and butane, and aromatic hydrocarbons, such as benzene, toluene and xylene, usually categorized as BTX substances. In leaking conditions, these by-products can contaminate the soil and underground water, or, when in the volatile form in the atmosphere, they can be a risk to public safety and health (Bruell and Hoag, 1984). Fuel underground storage tanks

\footnotetext{
Author for correspondence
} 
represent a potential source of contamination, in which the level and type of risk depend on the way the fuel is managed, as well as on the landscape structural characteristics (soil type, river network, etc) of the urban area where they are.

Informations based on the georeferenced mapping and overlaying of gas stations in relation to social and hydro-geological characteristics of the urban landscape are of great importance for the development of programs designed to reduce risks to health and public safety and risks of soil and water contamination. This paper provides an environmental diagnosis related to São Carlos'urban areas running potential risks of having their soil, surface water and underground water contaminated as a result of likely leaking of fuel underground storage tanks.

\section{MATERIAL AND METHODS}

The São Carlos county is located in the central region of the São Paulo State, Brazil, between the coordinates $44^{\circ} 55^{\prime}$ and $47^{\circ} 50^{\prime} \mathrm{W}$ and $21^{\circ} 00^{\prime}$ and $22^{\circ} 30^{\prime} \mathrm{S}$ (Fig. 1). It covers an area of approximately $416.81 \mathrm{~km}^{2}$, of which about $52 \mathrm{~km}^{2}$ correspond to a urban area, with a low green area index (Oliveira, 1996). São Carlos' climate can be classified as subtropical humid (Nimer, 1972), with hot and humid summer seasons and dry winter seasons. São Carlos has a humid and hyperthermal climate in the areas where the altitude is below 1,000 meters, whereas in regions above 1,000 meters it has a thermal climate (Oliveira, 1996). The mean values of precipitation and relative humidity are $1512 \mathrm{~mm}$ and $66 \%$, respectively. The region's hydric balance reveals that the groundwater level represents, on average, from $1 / 4$ to $1 / 3$ of monthly precipitation, what characterizes it as a recharge area of the Botucatu aquifer (Mattos, 1984).

The municipality of São Carlos is within the seventh ecological region of the State of São Paulo, on "basaltic cuestas" with altitudes from
800 to 900 meters (Troppmair, 1975). The main streams draining the urban area are Monjolinho, Mineirinho, Gregório, Tijuco, Medeiros, Lazarini, Água Quente and Água Fria. The most of them has theirs springs within the municipality area. The Monjolinho stream limits topographically, on the cuesta reverse, the region where most of the urban area is located (Gonçalves, 1986). Districts that have been growing recently, such as Cidade Aracy and Santa Felícia, are in the right watershed of Monjolinho stream (Oliveira, 1996).

Data collection about gas stations included the following information: name, address and georeferenced location in the urban area; flag; number of gas pumps referring to each type of stored fuel; period during which they were on operation in 2003; total number of underground storage tanks and total storage capacity per type of fuel in 2003. Gas stations were grouped in two categories, based on how they operate (http://www.anp.gov.br): commercial gas stations which only buy fuel from a wholesale distributor and sell it on a retail basis, and restricted gas stations for the private use of specific companies or institutions.

The identification and environmental diagnosis of the areas presenting potential risks of soil, surface water and underground water contamination were obtained by overlaying the georeferenced gas stations thematic chart on the following urban area thematic charts: river basins; pedology; population density (Oliveira et al., 1999); high risk areas of $100 \mathrm{~m}$ (Resolution CONAMA 273, of 29/Nov/2000) with reference to the river network and to 19 water pumping stations supplying urban and private consumers, and high risks areas of 150 m (Municipal Law 13217 of 01/Oct./2003) as a minimum distance of gas stations from a total of 93 public usage areas. Such kind of areas included state public schools (29), local public schools (28), private schools (17), health care centers (08), day care centers (8) and hospitals (03). 


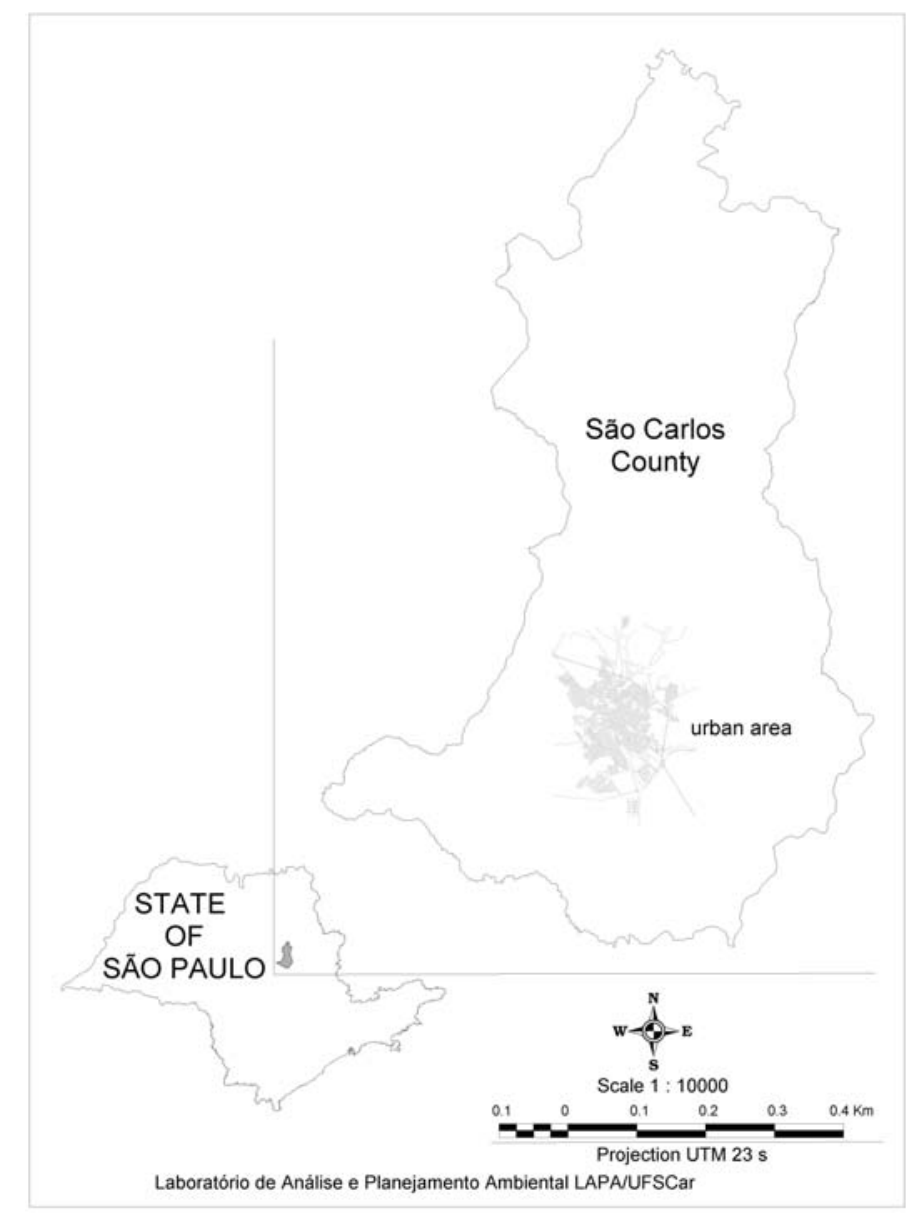

Figure 1 - Geographical location of the São Carlos county, São Paulo State.

The urban areas thematic charts (river basins, river network, pedology, urban roadnet and population density) were obtained based on the charts from the Geographic and Cartographic Institute for the São Carlos city and on the utilization of the GISIDRISI software.

\section{RESULTS AND DISCUSSION}

General information regarding gas stations such as name, address, and other aspects, as well as the landscape structural elements of the urban area where they are located, are available in a database (http://www.lapa.ufscar.br). There has been a significant increase in the number of gas stations in São Carlos city for the last 18 years. In 1985, there were only 25 gas stations (Gonçalves, 1991). In 2003, these gas stations were 64 in the urban area, 58 of which referred to dealers with commercial purposes and 6 gas stations restricted to companies and/or institutions. The total number of gas stations covered an area of $52 \mathrm{~km}^{2}$, totaling 291 underground storage tanks, 16 of which were related to restricted gas stations. This survey did not take into account fuel aerial storage tanks confined to some private companies.

About $40 \%$ of gas station have been operating for more than 15 years; $12 \%$ of them, from 10 to 15 years, and approximately $48 \%$ for less than 10 years (Fig. 2). It is important to note that the period during which a gas station operates is not the only factor for the analysis of the potential risk of fuel leaking. The age of underground storage tanks should also be considered, particularly because older gas stations could have replaced their underground storage tanks, and newer gas stations can have new facilities but old underground storage tanks. Approximately $44.5 \%$ of underground storage tanks in São Carlos city are in gas stations that have been operating for more than 15 years (Fig. 2), indicating potential 
leaking risks and likely contamination of soil and underground water. The legislation establishes that underground storage tanks shall be replaced within a 5-year period at the most (Resolution CONAMA 319 , of 04/Dec/2002).

The Europe and the United States experiences showed that gasoline underground storage tanks corroded and leak for an average period of 20 years after installed, in many cases, in 15 years, if they did not have a cathodic protection. It has been evidenced that $71 \%$ of gasoline underground storage tanks leak 10 years after they were installed, whereas some $46 \%$, in 15 years, compared to $53 \%$ of leaking in pipeline that took place 10 years after installation, and $77 \%$, in 15 years (Oliveira, 1992).

Little has been published about gasoline leakage in São Paulo. Virtually no data are available about São Carlos. This happens because environmental agencies are notified only in exceptional situations of visible fuel leaking that represents risk to the public safety and health.

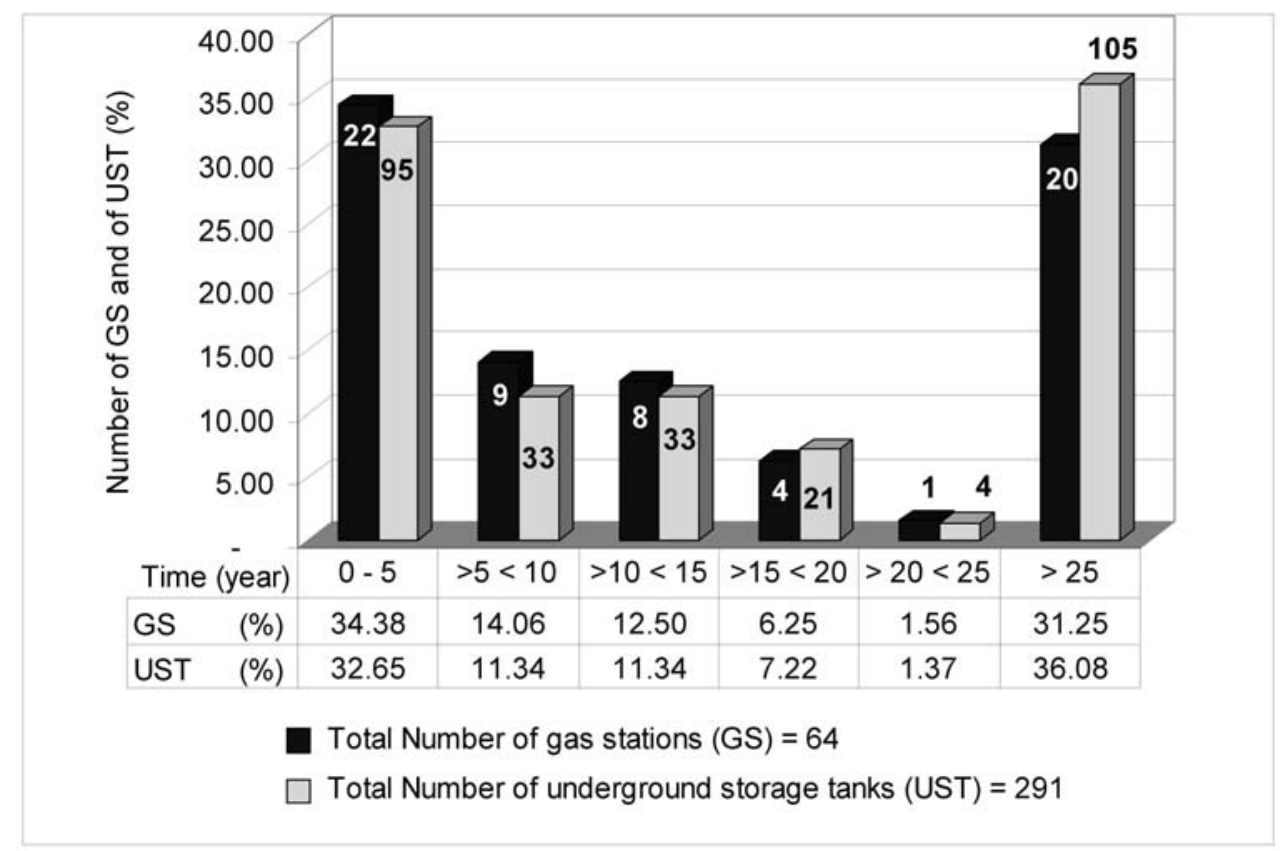

Figure 2 - Total number of gas stations (GS) and of underground storage tanks (UST) of São Carlos city as a function of operation time (2003).

According to data from CETESB of May/2002 out of 255 notifications about contaminated areas in the State of São Paulo, 60 referred to gasoline leakage in gas stations (http://www.cetesb.sp.gov.br). In case of accidents or leaking that may be a risk to the society, the responsible party is the owner or the person in charge of the establishment. The fuel supplier shall help as regards measures to control the emergency situation and to solve problems in the impacted area, according to the requirements established by the environmental agency. In most cases, the existence of leakage is reported to the owner by the distributor, and sometimes the local authorities are not informed about the fact.
The total fuel storage capacity in the city of São Carlos in 2003 was estimated at 4,595,000 liters, $1,230,000$ liters of which referring to fuel alcohol, 1,595,000 liters to conventional gasoline, 595,000 liters to premium gasoline, 1,100,000 liters to diesel, 60,000 liters to premium diesel and 15,000 liters to kerosene, distributed among 64 gas stations and 291 underground storage tanks (Table 1 ). Of the total, approximately $6 \%$ had a capacity of more than 30,000 liters. The concern about the 30,000 liter-tank limit (Item h, Article $6^{\text {th }}$ of Municipal Law 12349 of $04 / \mathrm{Jan} / 2000$ ) is important since it can reduce the risks associated to leaking volumes and to the types of fuels stored. Commercial and restricted gas stations were 
distributed only in 6 river basins: Monjolinho Nascente Urbana; Mineirinho; Tijuco; Gregório; Medeiros e Água Quente (Table 1).

The Gregório river basin showed the higher potential of soil and underground water contamination risk as a result of likely fuel leakage from underground storage tanks and from its pipelines. It comprised 30 gas stations, 146 underground storage tanks, with a total volume of 2,315,000 liters of fuel (Table 1). The risk was higher considering that about $60 \%$ of the gas stations in Gregório river basin was operating for more than 15 years, and also due to the geological characteristics of the soils (soil permeability and level of corrosion) where they were located.

Although they have not been subject of study, the environmental diagnosis of risks associated to the existing and potential leaking in underground storage tanks is highly dependent on the way fuels behave in different types of soils, which is influenced by the physical and chemical properties of liquid fuels (density, viscosity, solubility and vapor pressure) and by the characteristics of the soils through which these fuels migrate (Guiguer, 1996).

Table 1. Total number of commercial gas stations (CGS), restricted gas stations (RGS), underground storage tanks (UST), and of volumes of different stored fuel by river basin delimited for São Carlos city in 2003.

\begin{tabular}{|c|c|c|c|c|c|c|c|c|c|c|}
\hline river basins & $\begin{array}{l}\text { number } \\
\text { of CGS }\end{array}$ & $\begin{array}{c}\text { number of } \\
\text { RGS }\end{array}$ & $\begin{array}{c}\text { number of } \\
\text { UST }\end{array}$ & $\begin{array}{l}\text { alcohol } \\
\text { (L) }\end{array}$ & $\begin{array}{l}\text { gasoline } \\
\text { (L) }\end{array}$ & $\begin{array}{l}\text { premium } \\
\text { gasoline } \\
\text { (L) }\end{array}$ & $\operatorname{diesel}(\mathrm{L})$ & $\begin{array}{l}\text { premium } \\
\text { diesel }(L)\end{array}$ & kerosene $(L)$ & total volume $(\mathrm{L})$ \\
\hline $\begin{array}{l}\text { A- Monjolinho Nascente } \\
\text { Rural }\end{array}$ & -- & --- & -- & -- & -- & -- & -- & -- & -- & -- \\
\hline $\begin{array}{l}\text { B - Monjolinho Nascente } \\
\text { Urbana }\end{array}$ & 07 & 04 & 40 & 135,000 & 165,000 & 75,000 & 195,000 & -- & -- & 570,000 \\
\hline $\mathrm{C}-$ Mineirinho & 10 & -- & 44 & 185,000 & 315,000 & 45,000 & 175,000 & 15,000 & -- & 735,000 \\
\hline $\mathrm{D}$ - Tijuco & 06 & 01 & 30 & 120,000 & 150,000 & 90,000 & 135,000 & -- & -- & 495,000 \\
\hline E-Gregório & 29 & 01 & 146 & 660.000 & 800,000 & 330,000 & 465,000 & 45,000 & 15,000 & $2,315,000$ \\
\hline F- Medeiros & 02 & -- & 14 & 60,000 & 60,000 & 30,000 & 60,000 & -- & -- & 210,000 \\
\hline G - Água Quente & 04 & -- & 17 & 70,000 & 105,000 & 25,000 & 70,000 & -- & -- & 270,000 \\
\hline $\mathrm{H}-\mathrm{Sul}$ & -- & -- & -- & -- & -- & -- & -- & -- & -- & -- \\
\hline I - Água Fria & -- & --- & -- & -- & & -- & -- & -- & -- & -- \\
\hline TOTAL & 58 & 06 & 291 & $1,230,000$ & $1,595,000$ & 595,000 & $1,100,000$ & 60,000 & 15,000 & $4,595,000$ \\
\hline
\end{tabular}

The potential leaking from fuel undergrounded stored tanks is also related to a high contamination risk of underground water due to the soil characteristics of the urban area of São Carlos city. A total of 47 gas stations were located on Eutrophic LITHOLIC NEOSOL, 14 on Dystrophic LITHOLIC NEOSOL, 1 on Tipic Orthic QUARTZARENIC NEOSOL, 1 on Eutroferric RED LATOSOL and 1 on Dystrophic RED YELLOW LATOSOL (Fig. 3). LATOSOLIC SOIL are sandy with a faster drainage as regards possible hydrocarbon leakage and are extremely acid which could intensify the corrosion process of fuel underground storage tanks. In addition, the low percentage of organic matter in these soils facilitates the leaking of hydrocarbons. LITHOLIC NEOSOLS are clayey, with a little percentage of gravels, shallow, found nearby rivers and streams. They present a high amount of retained water due to the high levels of clay and organic matter, and they are one of the most fertile soils in the study area. They are acid and very rich in nutrients. They tend to retain, in a higher percentage, possible leaking of hydrocarbons due to the level of clay and larger quantity of organic matter, forming a permanent layer of contaminant. This layer can be ruptured during the dry season, leading to the direct leaking of hydrocarbons to deeper layers. Tipic Orthic QUARTZARENIC NEOSOLS are deep, sandy, acid and extremely drained, with a low fertility, and can present groundwater level fluctuation. These characteristics lead to the fast draining of possible leaking of hydrocarbons to deeper layers, which can reach the water table. The fluctuations in the groundwater level can lead to changes in the compactness of the soil surrounding the underground fuel tanks and in suction lines, causing them to break. 


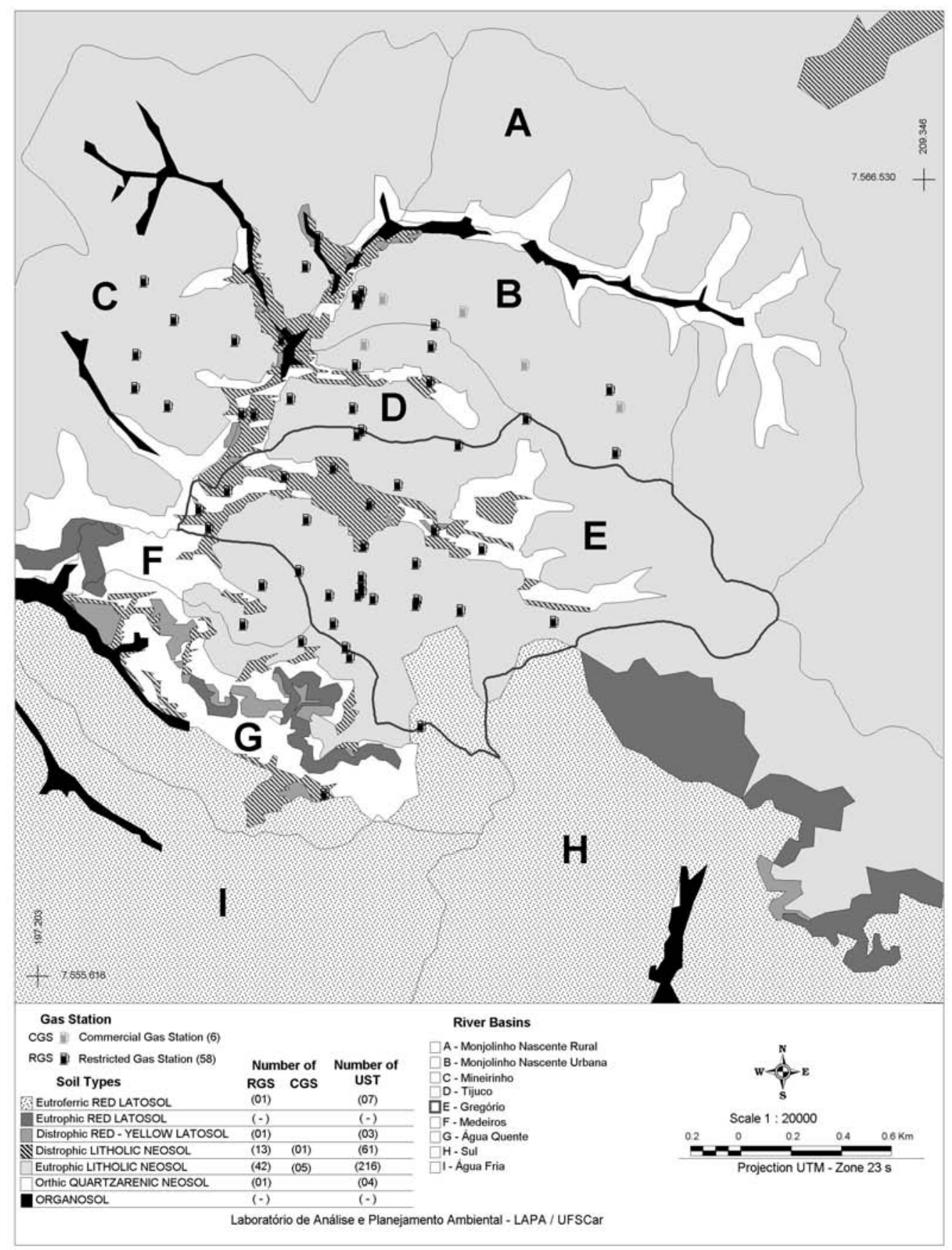

Figure 3 - Total number of gas stations (GS), of underground storage tanks (UST), and soil types in relation to São Carlos river basins. Gregório river basin (E), with 30 gas stations and 146 underground storage tanks has the higher potencial of soil and underground water contamination risks.

The proximity of gas stations to surface water streams and to the water pumping stations supplying the public and private sectors is a potential risk of contamination of surface and underground water, intensified by the high impermeabilization of the urban soil, what facilitates the dragging of pollutants during the rainy season. In São Carlos urban area, approximately $15 \%$ (10) of gas stations are in high risk areas $(100 \mathrm{~m})$ in relation to surface water streams. Of that total, five gas stations are in the high risk area of Gregório river. Only two gas 
stations are in water pumping station high risk area. This also happens for the Gregório river basin (Fig. 4).

The gas stations distribution related to the population density showed that São Carlos city had a high volume of stored fuel in lower populated area, although most of gas stations were not there (Table 2). It reflected a pattern of spatial distribution seen downtown, which was the historical and structural landmark as regards the urban growth.

At least $33(35 \%)$ public usage areas (schools, hospitals, day care centers and health care centers) had gas stations within the high risk area of $300 \mathrm{~m}$ (Municipal Law 12349 of 04/Jan/2000). In this aspect, the Gregório river basin could also be presented as the most jeopardized, with 16 public usage areas with gas stations within high risk areas. However, the minimum distance of gas stations from such public usage areas was reduced from 300 to $150 \mathrm{~m}$ (Municipal Law 13217, $01 /$ Oct $/ 2003$, with the new wording given by Item b, Article $5^{\text {th }}$ of Municipal Law 12349 of 04/Jan/2000). This change in legislation led to a reduction from $35.5 \%$ (33) to $9.5 \%$ (9) of the total number of public usage areas with potential risks to the users of these facilities (Fig. 5). This provision of legal restriction resulted the current urban scenario where most of public usage areas have not been located in gas station of potential risk areas.

Table 2 - Total number of gas stations and volume of stored fuel in relation to the areas with different population densities of São Carlos city.

\begin{tabular}{|c|c|c|}
\hline $\begin{array}{l}\text { Kind of areas related to the population density } \\
\qquad(*)\end{array}$ & $\begin{array}{l}\text { Total volume (l) of } \\
\text { stored fuel }\end{array}$ & $\begin{array}{c}\text { Number of gas stations in the } \\
\text { area }\end{array}$ \\
\hline $\begin{array}{c}\text { High density } \\
6.000-12.000 \mathrm{hab} / \mathrm{km}^{2}\end{array}$ & 1.415 .000 & 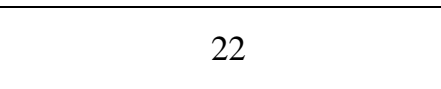 \\
\hline $\begin{array}{c}\text { Mean density } \\
3.000-6.000 \mathrm{hab} / \mathrm{km}^{2}\end{array}$ & 1.695 .000 & 24 \\
\hline $\begin{array}{c}\text { Low density } \\
0-3.000 \mathrm{hab} / \mathrm{km}^{2}\end{array}$ & 1.485 .000 & 18 \\
\hline
\end{tabular}

${ }^{(*)}$ OLIVEIRA et al. (1999).

\section{CONCLUSIONS}

It is necessary to recognize and identify gas stations as a potential source of environmental contamination for the management of hazardous substances from the environment and public safety points of view for a better environmental and life quality. The number of gas stations in the São Carlos city is relatively high, $44.5 \%$ of which operating from more than 15 years, located in soils that present a potential risk of underground water contamination; a large impermeable area that facilitates the draining of pollutants to surface waters; a high concentration of gas stations in areas with a high and mean population density, some of which meaning potential risks to the users of public areas such as schools, day care centers, health care centers and hospitals.

Although the results presented in this paper could not be considered important for the prevention of fuel leaking into the soil and water, they assumed significance to evaluate the potential risks related to gas stations in the São Carlos city. They revealed the urgency of both establishing public policies designed to the environmental planning, and of improving rules and laws related to the control and prevention of leakage and dispersion in fuel underground storage tanks. Attention should be devoted to public policies and research agencies regarding gas stations, as well as the need of bringing to the community knowledge the environmental problems and risks that gas stations may could pose.

However, for a precise environmental diagnosis of the gas stations potential risks of São Carlos city, could be necessary to conduct a more comprehensive study about the existence or not of leakage in commercial and restricted underground fuel tanks. 


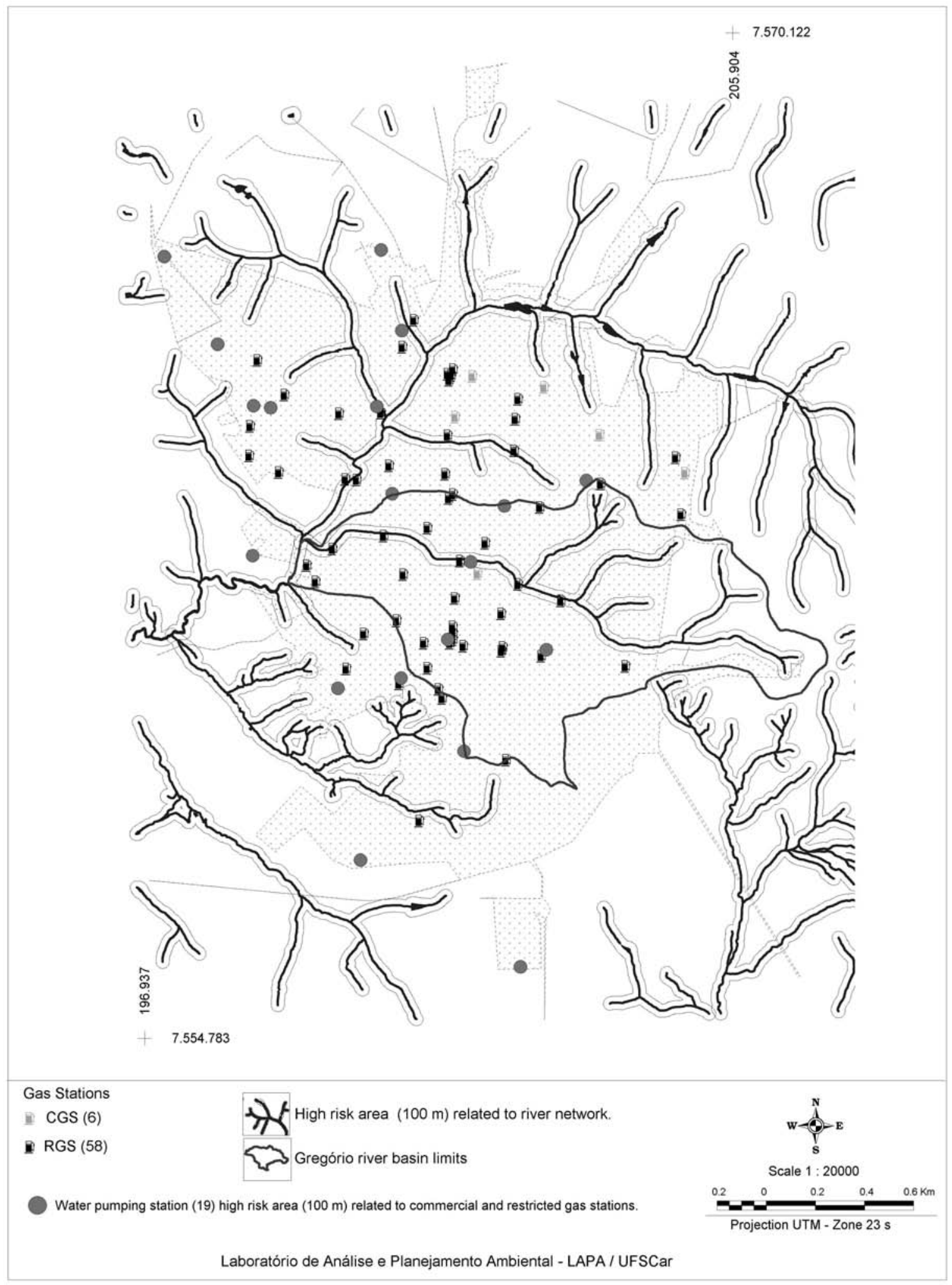

Figure 4 -Location of commercial gas stations (CGS) and restricted gas stations (RGS) in relation to river network and to the water pumping stations high risk areas of São Carlos city. At least 10 gas stations are in high risk area $(100 \mathrm{~m})$ in relation to river network, 05 of wich are in Gregório river high risk area. Only two gas stations are in water pumping station high risk area. 


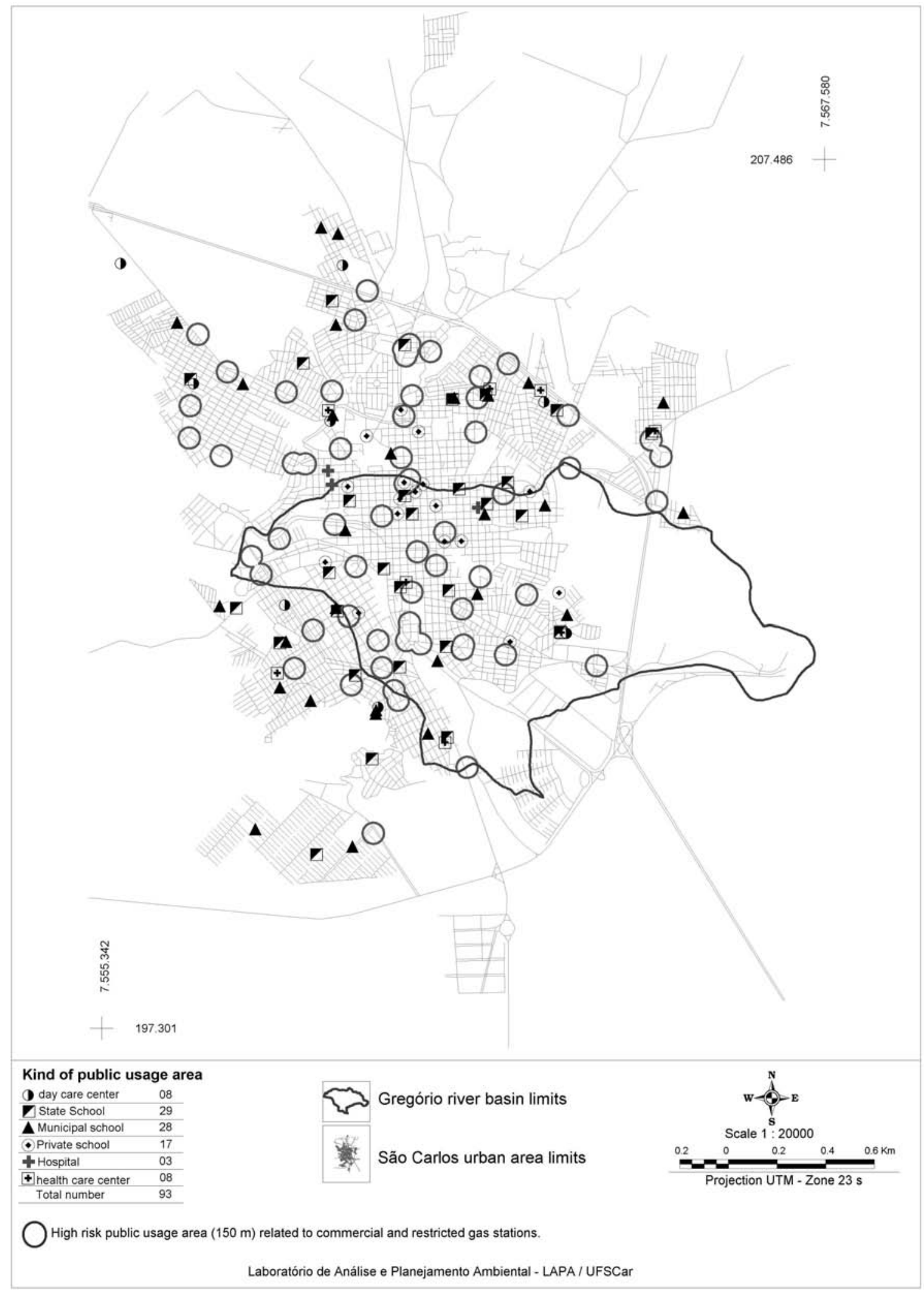

Figure 5 - Location of high risk areas (schools, hospitals, day cares and health care centers) related to commercial and restricted gas stations in São Carlos city. Only 09 public usage areas have gas stations within the high risk area (Municipal Law 13217 of 01/Oct/2003). The Gregório river basin has 03 public usage areas with gas stations located in high risk areas. 


\section{ACKNOWLEDEGEMENTS}

The authors thank FAPESP for financial support. (Proc. 01/13459-4).

\section{RESUMO}

Foram realizados a localização e o mapeamento dos postos de combustíveis da área urbana do município de São Carlos, SP, para um diagnóstico ambiental relacionado aos riscos de contaminação do solo e das águas superficial e subterrânea em decorrência de prováveis vazamentos dos tanques de armazenamento subterrâneo de combustível. A área urbana da cidade de São Carlos apresenta um total de 64 postos de combustíveis, 58 dos quais com fins exclusivamente comerciais; um volume potencial de combustível armazenado de 4.595.000 1 associado a um total de 291 tanques de armazenamento subterrâneo, $40 \%$ dos quais associados a postos que funcionam a mais de 15 anos; localizados em terrenos com características geológicas de risco potencial para a contaminação das águas subterrâneas, e concentradas em áreas urbanas com alta e média densidade populacional. Considerando que um dispostivo de restrição legal possibilita que a maioria das áreas de uso público (escolas, creches, postos de saúde e hospitais) esteja localizada externa as áreas críticas de riscos potenciais aos usuários das mesmas, estas informações são extremamente úteis para o desenvolvimento de programas voltados à redução dos riscos à segurança e a saúde pública e à contaminação do solo e da água subterrânea.

\section{REFERENCES}

Bruel, C. J. and Hoag, G. E. (1984), Capillary and Packed - Column Gas Chromatography of Gasoline Hydrocarbons and EDB. Conference and Exposition on Petroleum Hydrocarbons and Organic Chemicals in Ground Water- Prevention, Detection and Restoration, November, National Water Well Association. pp. 5-7.

Canter, L. W.; Robert C. and Fairchild, D. M. (1988), Ground Water-Quality Protection, Lewis Publishers, Inc.

Gonçalves, A. R. L. (1986), Geologia Ambiental em São Carlos. Dissertação de Mestrado, EESC-USP, São Carlos, SP. (Inst. de Geociências).
Gonçalves, A R. L. (1991), Geologia Ambiental em São Carlos-Solos. In: Seminário Regional de Ecologia da UFSCar, São Carlos. Anais... São Carlos, SP.

Guiguer, N. (1996), Poluição das Águas Subterrâneas e do Solo Causada por Vazamentos em Postos de Abastecimento e Serviços. Editor Waterloo Hydrogeologic, USA.

Lorandi, R. (1985), Caracterização dos Solos da área Urbana e Suburbana de São Carlos (SP) e suas Aplicações. Dissertação (Mestrado). ESALQ, USP, Piracicaba, SP.

Mattos, A. (1984), Bacia Representativa do Rio JacaréGuaçú, Publicação Convênio EESC-DNAEE. São Carlos, SP.

Nimer, J. (1972), Climatologia da Região Sudeste do Brasil: Introdução à Climatologia Dinâmica, subsídios à Geografia Regional do Brasil. Revista Brasileira de Geografia, 34, 3-48.

Oliveira, C. H. (1996), Planejamento Ambiental na Cidade de São Carlos (SP) com ênfase nas áreas públicas e nas áreas verdes: diagnóstico e propostas. Dissertação de Mestrado, UFSCar, São Carlos, SP.

Oliveira, C. H.; Santos, J. E. and Pires, J. S. R. (1999), Indicadores de arborização urbana da cidade de São Carlos (SP) com o uso do SIG-IDRISI. Brazilian Journal of Ecology, 3, 1-9.

Oliveira, E. (1992), Contaminação de Aqüíferos por Hidrocarbonetos Provenientes de Vazamentos de Tanques de Armazenamento Subterrâneo. Tese (Doutorado), Instituto de Geociências, USP, São Paulo.

Pearson, G. and Oudjikg, R. (1993), Investigation and Remediation Petroleum product releases from residential storage tanks. Ground Water Monitoring Review, 13, 124-128.

Troppmair, H. (1975), Regiões Ecológicas do Estado de São Paulo: Biogeografia, 10, 1-24.

U. S. Environmental Protection Agency (1984), A Ground Water Protection Strategy for Environmental Protection Agency-Draft, January, Washington D.C.

U. S. Environmental Protection Agency (1985a), Water Quality Assessment: A Screening Procedure for Toxic and Groundwater. EPA/600/6-85/002 a and EPA/600/6-85/002b. Athens, GA, Environmental Research Lab.

U.S. Environmental Protection Agency (1985b), RCRA Orientation annual. EPA/530/SW/86/001. Office of Solid Waste.
Received: May 26, 2004; Revised: October 15, 2004; Accepted: May 19, 2005. 